Janusz Wdzięczak

University of Lodz, Faculty of Economics and Sociology

Institute of Economics

e-mail: js.wdzieczak@vp.pl

\title{
Funkcjonowanie samorządów pracowniczych w wybranych krajach realnego socjalizmu
}

\section{Workers' Self-Management in the Selected Countries of the Real Socialism Socio-Economic System}

The aim of the article is to present the attempts of establishing institutions of a system of worker's self-management in the selected countries of the so-called real socialism system in Eastern Europe. The analysis considers three of those countries, namely Yugoslavia, Poland and Hungary, whose experiences in participation of the employees' implementation were the most significant. Particular attention was paid to the evolution of socialist regimes approach to workers' self-management. The paper tries to answer the question whether workers' self-management posed a threat to the socialist regimes persistence. The research method used in the study is an indepth survey and analysis of literature and legal acts.

Keywords: self-management, employee participation, socialist economies

JEL Classification: J51, N34, P31

\section{Uwagi wstępne}

Zagadnienia dotyczące samorządu pracowniczego i szeroko pojmowanej partycypacji pracowniczej są częstokroć poruszane we współczesnej literaturze dotyczącej zarówno rynku pracy, jak i społecznej odpowiedzialności biznesu. W obu przypadkach rozważania odnoszą się jednak w głównej mierze do realiów gospodarki wol- 
norynkowej. Zdecydowanie mniejszą uwagę poświęca się natomiast analizie przykładów funkcjonowania samorządu pracowniczego w innych ustrojach społecznogospodarczych.

Idea zaangażowania pracowników w proces zarządzania przedsiębiorstwem była podnoszona już w pierwszej połowie XIX wieku przez socjalistów utopijnych, Charlesa Fourriera i Pierre'a Proudhona, którzy postulowali oparcie życia gospodarczego na wspólnotach produkcyjno-konsumpcyjnych zarządzanych samodzielnie przez skupionych w nich ludzi ${ }^{1}$. Brak sukcesów w funkcjonowaniu tego rodzaju jednostek skłaniał do poszukiwania innych rozwiązań opierających się na tej samej ogólnej zasadzie współudziału robotników w decydowaniu o działaniu przedsiębiorstw, w których byli zatrudnieni. Wydaje się, że największy wpływ na stworzenie takiego rozwiązania wywarła koncepcja Karola Marksa, a zwłaszcza sposób jej interpretacji przez władze Rosji po rewolucji październikowej. Marks w swoich licznych dziełach posunął się do twierdzenia, że całość środków produkcji powinna zostać przekazana $\mathrm{w}$ ręce klasy pracującej ${ }^{2}$, która to klasa powinna rozporządzać ich użytkowaniem. Zgodnie z odczytaniem tej koncepcji przez bolszewików, cała gospodarka miała być wprawdzie zarządzana przez klasę robotniczą, ale za pośrednictwem partii komunistycznej stanowiącej jej reprezentację. W ZSRR takie podejście zastosowano w praktyce. Partia bolszewicka sprawowała zarówno bezpośrednią kontrolę nad całą gospodarką (poprzez wpływ na organy administracji centralnej), jak i kontrolowała poszczególne przedsiębiorstwa w sposób bezpośredni (poprzez funkcjonujące w każdym z nich komórki partyjne) $)^{3}$.

Po zakończeniu II wojny światowej do obrania podobnej drogi zostały zmuszone również inne państwa, które znalazły się w radzieckiej strefie wpływów. W krajach, w których zaczęto wprowadzać system nakazowo-rozdzielczy dominującą rolę w nadzorze nad podmiotami gospodarczymi zaczęły pełnić partie socjalistyczne lub komunistyczne, które na poziomie deklaratywnym miały reprezentować interesy wszystkich pracowników, lecz w praktyce pozostawały jednak narzędziem sprawowania władzy przez partyjne elity. Pomimo tego rodzaju nadrzędnej zasady funkcjonowania gospodarek tzw. realnego socjalizmu, w efekcie różnego rodzaju zawirowań politycznych i ekonomicznych niekiedy dochodziło jednak do prób tworzenia w tych krajach samorządów pracowniczych z prawdziwego zdarzenia, czyli takich, dzięki którym pracownicy zyskiwali faktyczny wpływ na zarządzanie przedsiębiorstwem.

Celem artykułu jest przedstawienie prób tworzenia i rozwoju instytucji samorządu pracowniczego w oparciu o analizę przykładów zaczerpniętych z historii gospodarczej wybranych krajów należących do bloku wschodniego w drugiej połowie $\mathrm{XX}$ wieku, a także podniesienie kwestii ewolucji stosunku reżimów socjalistycz-

\footnotetext{
${ }^{1}$ Cf. R. Heilbroner, Wielcy ekonomiści. Czasy, życie, idee, PWE, Warszawa 1993, s. 92-119.

${ }^{2}$ Postulat przekazania środków produkcji pod kontrolę klasy pracującej pojawia się np. w Kapitale (1867) czy Manifeście partii komunistycznej (1848).

${ }^{3}$ Wyjątek stanowił okres mający miejsce bezpośrednio po rewolucji lutowej, a także rewolucji bolszewickiej, kiedy to rady robotnicze uzyskały bezpośredni wpływ na kierowanie przedsiębiorstwami na terenie Rosji. Cf. M. Heller, A. Niekricz, Utopia u wtadzy. Historia ZSRR od 1917 do dziś, Wydawnictwo CDN, Warszawa 1986.
} 
nych do idei partycypacji robotniczej. Pod uwagę zostały wzięte trzy państwa - Jugosławia, Polska i Węgry - w których doświadczenia z partycypacją pracowniczą były najbardziej znaczące spośród krajów realnego socjalizmu. Dla umieszczenia prowadzonych rozważań w kontekście historycznym w artykule krótko nakreślone zostały uwarunkowania polityczne, podstawy prawne tworzenia samorządu pracowniczego oraz rezultaty inicjatyw podejmowanych w tym obszarze. Przyjęta metoda badawcza opiera się na studiach literaturowych.

\section{Funkcjonowanie samorządów pracowniczych w Jugosławii}

Dorobek Jugosławii w zakresie tworzenia samorządu pracowniczego zasługuje na omówienie w pierwszej kolejności ze względu na wagę i masowość tego zjawiska w tym kraju. Rozwój samorządów pracowniczych był podyktowany względami politycznymi. W końcowym okresie II wojny światowej Jugosławia została wyzwolona przez armie partyzanckie Josipa Broz Tito, a nie przez Armię Czerwoną, tak jak np. Polska czy Węgry. Z tego powodu wojska radzieckie nigdy nie okupowały Jugosławii, a pozycja polityczna Tito, który po wojnie stał się przywódcą państwa, była niezwykle silna. Co za tym idzie - mógł on sobie pozwolić na daleko idącą samodzielność. Stało się to powodem konfliktu ze Stalinem, który nie tolerował samodzielności Jugosławii. W efekcie w 1948 roku Jugosławia zerwała kontakty z ZSRR i z resztą obozu socjalistycznego, co spowodowało jej polityczną i gospodarczą izolację. Do poprawy stosunków doszło dopiero w latach 50. XX w., jednak Jugosławia nadal utrzymała daleko idącą niezależność.

Rozbieżności polityczne znalazły odzwierciedlenie w kwestiach ekonomicznych. Po roku 1948 Jugosławia nie mogła liczyć na współpracę gospodarczą z innymi państwami socjalistycznymi. Jednocześnie niezależność od ZSRR umożliwiała wprowadzenie rozwiązań innych niż wzorowane na modelu radzieckim. Wszystko to skłoniło władze Jugosławii do szukania własnego modelu ustroju gospodarczego.

$\mathrm{Na}$ początku lat 50. XX wieku rozpoczęto przeprowadzanie licznych reform mających na celu wprowadzenie elementów samorządności w gospodarce. Obejmowały one zarówno kwestie związane z tworzeniem samorządów pracowniczych, jak i ze zwiększaniem autonomii przedsiębiorstw. Zapisy o samorządności podmiotów gospodarczych znajdowały się w przyjętej w 1953 roku Konstytucji Jugosławii. Podobny wydźwięk miała kolejna konstytucja przyjęta w 1963 r., która samorządność wprowadzała dodatkowo w sektorach nieprodukcyjnych (np. nauce, edukacji czy kulturze $)^{4}$.

W 1950 roku zainicjowano proces tworzenia instytucji samorządu robotniczego w jugosłowiańskich przedsiębiorstwach państwowych. Idea samorządu robotniczego uznawana była przez jugosłowiańskich komunistów za początek histo-

\footnotetext{
${ }^{4}$ A. Fornalczyk, Jugostowiański system gospodarczy 1950-1976, Wydawnictwo Łódzkie, Łódź 1979, s. $19-20$.
} 
rycznego procesu przekształcania własności społecznej z jej niższej formy - własności państwowej, $w$ wyższa forme - własności socjalistycznej, tzn. w zarzadzanie własnością ogólnonarodowa przez bezpośrednich wytwórców ${ }^{5}$. Sama koncepcja zakładała przekazanie uprawnień w zakresie podejmowania decyzji dotyczących zarówno kwestii bieżących, jak i rozwojowych, pracownikom. W zamyśle miało to spowodować zwiększenie świadomości społecznej i wytworzyć postawę odpowiedzialności wszystkich obywateli za efekty osiągane przez zarządzane przez nich podmioty. Docelowo planowano stopniowe zastępowanie administracji państwowej w obszarze koordynowania procesów gospodarczych przez samorząd. Ponadto pracownicy, poza możliwością decydowania o własnym przedsiębiorstwie, mieli uzyskać pewien wpływ na funkcjonowanie całej gospodarki poprzez organy przedstawicielskie $^{6}$.

Według przyjętych w 1950 roku regulacji, organami samorządu pracowniczego miały być: rada pracownicza i komitet zarządzający. W skład rady wchodziło od 5. do 120. przedstawicieli załogi wybieranych na dwuletnie kadencje, przy czym nie można było sprawować funkcji dłużej niż dwie kadencje. Rada wybierała przewodniczącego i zastępcę, którzy kierowali jej pracami. Do jej kompetencji należało $^{7}$ :

(1) zatwierdzanie projektu statutu przedsiębiorstwa,

(2) zatwierdzanie planów przedsiębiorstwa,

(3) ustalanie planu rocznej działalności przedsiębiorstwa,

(4) uchwalanie funduszu płac,

(5) powoływanie członków komitetu zarządzającego,

(6) powoływanie (na podstawie konkursu) dyrektora przedsiębiorstwa.

Komitet zarządzający był ciałem wykonawczym, którego zadaniem było realizowanie uchwał rady pracowniczej. W skład komitetu wchodziło od 3. do 11. członków, w tym dyrektor przedsiębiorstwa. Obowiązywała zasada, że przynajmniej 3/4 składu komitetu powinno się wywodzić z grupy pracowników bezpośrednio zatrudnionych przy produkcji lub obszarze stanowiącym podstawową działalność przedsiębiorstwa, co miało na celu ograniczenie wybierania do komitetów przedstawicieli administracji. Do kompetencji komitetu zarządzającego należało ${ }^{8}$ :

(1) opracowywanie projektów planów przedsiębiorstwa,

(2) przygotowywanie projektów zmian organizacyjnych,

(3) powoływanie pracowników na stanowiska kierownicze.

Szczegółowy zakres kompetencji poszczególnych organów kolektywnych, jak i kadry kierowniczej, określał statut przedsiębiorstwa. Ponadto wszyscy pracownicy uzyskali możliwość wywierania bezpośredniego wpływu na decyzje poprzez prawo głosu na walnych zgromadzeniach załogi i możliwość udziału w referendach, podczas których podejmowano najważniejsze decyzje (np. dotyczące powołania lub likwidacji jednostek przedsiębiorstwa). System ten okazał się jednak niedostosowany

\footnotetext{
5 Ibidem, s. 24.

${ }^{6}$ Ibidem, s. 24-26.

${ }^{7}$ S. Krajewski, System zarządzania w przemyśle jugosłowiańskim, Książka i Wiedza, Warszawa 1975, s. 34-35.

${ }^{8}$ A. Fornalczyk, op. cit., s. $28-29$.
} 
do zbyt dużych liczebnie załóg. Wobec tego od roku 1953 rozpoczęto reformy mające na celu decentralizację systemu samorządu pracowniczego. Powstały wydziałowe rady pracownicze, które miały umożliwiać załodze bezpośredni wpływ na pracę poszczególnych komórek organizacyjnych przedsiębiorstwa ${ }^{9}$.

Ideę samorządności starano się realizować także na poziomie wyższym. Przedsiębiorstwa mogły należeć do zrzeszeń przedsiębiorstw, które opierały się na powiązaniach produkcyjno-handlowych, a uczestnictwo w nich było dobrowolne. Następnie stworzono instytucję izb gospodarczych. Do roku 1958 członkostwo w nich było dobrowolne. Zadaniem izb było koordynowanie działań przedsiębiorstw i podejmowanie wspólnych inicjatyw. Ponadto przedsiębiorstwa mogły podpisywać ze sobą (również na zasadzie dobrowolności) porozumienia o współpracy w dowolnym obszarze. W 1962 roku utworzono republikańskie izby gospodarcze i Związkową Izbę Gospodarczą, której zadaniem było reprezentowanie wszystkich zrzeszonych w niej podmiotów wobec administracji rządowej ${ }^{10}$.

Rezultatem przedstawionych powyżej procesów było stworzenie ustroju gospodarczego opartego o samorządność pracowników i przedsiębiorstw. Charakterystyczna dla Jugosławii była przy tym masowość samorządności robotniczej. Według szacunków Stefana Krajewskiego, w roku 1970 w skład rad robotniczych i komitetów zarządzających w całej Jugosławii (liczącej wówczas 20 milionów obywateli) wchodziło około 200 tysięcy pracowników ${ }^{11}$.

\section{Polskie doświadczenia w działaniu samorządów pracowniczych w okresie PRL-u}

Odmiennie kształtowały się losy instytucji samorządu pracowniczego w Polskiej Rzeczpospolitej Ludowej (PRL). W przeciwieństwie do Jugosławii, Polska pozostawała pod dużym wpływem ZSRR. Pewne zmiany nastąpiły po wydarzeniach października 1956, kiedy to spontanicznie zaczęły powstawać rady robotnicze. Na fali mającej wówczas miejsce odwilży rozpoczęto nawet prace nad koncepcją reform gospodarczych ${ }^{12}$. Należy jednak zaznaczyć aż do lat 80 . XX wieku PRL pozostawała lojalnym członkiem szeroko rozumianego obozu socjalistycznego, co ograniczało reformy i uniemożliwiało skuteczne poszukiwanie polskiej wersji socjalizmu.

Dominującą rolę w życiu zarówno politycznym, jak i gospodarczym sprawowała Polska Zjednoczona Partia Robotnicza (PZPR). Powstała ona z połączenia Polskiej Partii Socjalistycznej i Polskiej Partii Robotniczej w 1948 roku mając się stać awangarda klasy robotniczej, najwyższej formy jej organizacji, przewodniej

\footnotetext{
${ }^{9}$ Ibidem, s. 31.

${ }^{10}$ Ibidem, s. 32-37.

${ }^{11}$ S. Krajewski, op. cit., s. 38.

${ }^{12}$ Mowa u o powołaniu Rady Ekonomicznej, na której czele stanął Oskar Lange. Rada prowadziła prace nad nowym modelem gospodarki socjalistycznej. Cf. J. Skodlarski, Historia gospodarcza, Wydawnictwo Naukowego PWN, Warszawa 2012, s. 410-411.
} 
sity rewolucji socjalistycznej ${ }^{13}$. Statut PZPR jasno określał jej rolę w państwie, także w obszarze samorządu robotniczego. Stwierdzał on wprawdzie, że partia pobudza działalność związków zawodowych i popiera rozwój samorządu robotniczego, ale jednocześnie zdecydowanie zwalcza wszelkie próby wykorzystania demokracji przez sity wsteczne dla celów wrogich socjalizmowi ${ }^{14}$. Statut nakładał na podstawowe organizacje partyjne PZPR działające w przedsiębiorstwach obowiązek zapewniania należytej sprawności pracy samorządowi robotniczemu, ale $\mathrm{z}$ drugiej strony uznawał, że jest nim również sprawowanie politycznej kontroli nad przedsiębiorstwem, która miała być dokonywana przez udział w pracach samorzadu robotniczego, zabezpieczając słuszne kojarzenie interesów załogi z interesami ogólnonarodowymi ${ }^{15}$. Tytułem komentarza należy stwierdzić, że przytoczone zapisy jasno stwierdzały, że to PZPR reprezentuje wszystkich pracowników przedsiębiorstw, a jej zadaniem jest kontrolowanie samorządu robotniczego i związków zawodowych. Stan ten potwierdziła Konstytucja PRL z 1976 roku, na mocy której PZPR została uznana ,przewodnią siłą narodu"16.

Regulacje te wprowadzono $\mathrm{w}$ życie poprzez stworzenie podporządkowanych PZPR związków zawodowych. Zostały one na podstawie odgórnych decyzji zgrupowane w Zrzeszeniu Związków Zawodowych ${ }^{17}$. Od momentu powstania Zrzeszenia do jego rozwiązania, na jego czele stali członkowie PZPR ${ }^{18}$. Podobnie rzecz miała się z radami pracowniczymi. Na mocy Dekretu o utworzeniu Rad Zakładowych powstała możliwość tworzenia rad reprezentujących pracowników w przedsiębiorstwach powyżej 20. osób. Rady takie miały jednak ograniczone kompetencje, działały jedynie w zakresie reprezentowania interesów pracowników, prowadzenia polityki kadrowej oraz niesprecyzowanej szerzej kontroli społecznej nad przedsiębiorstwem $^{19}$. Już w roku 1947 rady zakładowe utraciły znaczną część swoich uprawień stając się faktycznie związkami zawodowymi ${ }^{20}$. Od tego momentu w PRL pojęcie rad robotniczych zaczęło często występować zamiennie z pojęciem związków zawodowych.

Do krótkotrwałego wzmocnienia roli samorządu pracowniczego doszło we wspomnianym już okresie odwilży politycznej w roku 1956. W państwowych przedsiębiorstwach przemysłowych, budowalnych i rolnych mogły powstawać rady robotnicze, których zadaniem miało być zarządzanie w imieniu załogi przedsiębiorstwem będącym wtasnościa ogólnonarodową ${ }^{21}$. Do bezpośrednich zadań rad robotniczych miało należeć wytyczanie kierunków rozwoju przedsiębiorstwa, uchwalanie planów rocznych, decydowanie (na podstawie opinii kierownictwa) o zbyciu majątku przedsiębiorstwa i opiniowanie wniosku o powołanie dyrektora przedsię-

\footnotetext{
${ }^{13}$ Statut Polskiej Zjednoczonej Partii Robotniczej uchwalony przez III Zjazd PZPR, 1963, s. 7-8.

${ }^{14}$ Ibidem, s. 21-22.

15 Ibidem s. 109-117.

${ }^{16}$ Konstytucja Polskiej Rzeczpospolitej Ludowej 1976 r.

${ }^{17}$ Ustawa z dnia 1 lipca 1949 r. o związkach zawodowych.

${ }^{18}$ W. Roszkowski, Historia Polski, 1914-1990, Wydawnictwo Naukowe PWN, Warszawa 1991.

${ }^{19}$ Dekret z dnia 6 lutego 1945 r. o utworzeniu Rad Zakładowych.

${ }^{20}$ Dekret z dnia 16 stycznia 1947 r. o zmianie dekretu z dnia 6 lutego 1945 r. o utworzeniu Rad Zakładowych.

${ }^{21}$ Ustawa z dnia 19 listopada 1956 r. o radach robotniczych.
} 
biorstwa. Ponadto rady robotnicze miały decydować o podziale części zysku przypadającej załodze, co należy uznać za zapis przełomowy, gdyż oddawał on w ręce pracowników uprawienia do jego częściowej dystrybucji ${ }^{22}$. Uprawnienia te zostały jednak ograniczone już w 1958 roku poprzez ustawę o samorządzie robotniczym. Umożliwiała ona tworzenie obok rad robotniczych tzw. konferencji samorządu robotniczego. Obie instytucje dysponowały jednak skromnymi uprawnieniami, ograniczającymi się do opiniowania planów i nominacji dyrektorskich ${ }^{23}$, wobec czego można stwierdzić, że po roku 1958 w PRL samorząd pracownicy de facto przestał istnieć.

Do swoistej oddolnej reaktywacji samorządów pracowniczych doszło po wydarzeniach mających miejsce w sierpniu 1980 roku. Ich początek dało rozpoczęcie strajku w Stoczni Gdańskiej, której efektem było powstanie Międzyzakładowego Komitetu Strajkowego (MKS) stanowiącego reprezentację wszystkich strajkujących wówczas przedsiębiorstw. Ogłosił on słynną listę 21. postulatów skierowanych do władz, wśród których znalazło się żądanie możliwości tworzenia organizacji pracowniczych (punkt 1), a także dopuszczenia wszystkich grup społecznych do dyskusji nad programem reform (punkt 6$)^{24}$. Postulaty te zostały przyjęte przez władze, mimo że mogły stanowić potencjalny wyłom w monopolu PZPR na reprezentowanie interesu szeroko rozumianych mas pracujących. Rezultatem tego było tworzenie się oddolnie samorządów pracowniczych w przedsiębiorstwach, a następnie powstanie Niezależnego Samorządnego Związku Zawodowego „Solidarność”, którego komórki (komisje zakładowe, organizacje branżowe i regionalne) zaczęły organizować się na terenie całego kraju ${ }^{25}$. Warto przy tym podkreślić samo pojawienie się pojęcia „samorządny” w nazwie związku. W dyskusjach nad programem „Solidarności” obecne były bowiem kwestie związane z samorządem pracowniczym, takie jak na przykład tworzenie pracowniczych rad zakładowych ${ }^{26}$. Postulaty w kwestii stworzenia samorządu pracowniczego rozwinął I Krajowy Zjazd NSZZ „Solidarność” mający miejsce w 1981 roku. Delegaci w programie przyjętym przez Zjazd domagali się zbudowania nowej struktury organizacyjnej gospodarki postulując, $\mathrm{iz}[p]$ odstawowa jednostka organizacyjna gospodarki powinno stać się przedsiębiorstwo społeczne, którym zarzadza załoga reprezentowana przez rade pracownicza, a operatywnie kieruje dyrektor, powoływany droga konkursu przez radę i przez nia też odwoływany. Ponadto stwierdzano również, że [p]rzedsiębiorstwo społeczne będzie dysponować powierzonym mu mieniem ogólnonarodowym $w$ interesie społeczeństwa $i$ własnej załogi. Prowadzić będzie samodzielna działalność na zasadach rachunku ekonomicznego ${ }^{27}$.

„Solidarność” dążyła do zachowania dotychczasowych osiągnięć w zakresie rozwoju samorządności pracowniczej, czego przykładem była jedna z uchwał Zjazdu:

\footnotetext{
${ }^{22}$ Ibidem.

${ }^{23}$ Ustawa z dnia 20 grudnia 1958 r. o samorządzie robotniczym.

${ }^{24} \mathrm{http}$ ://www.solidarnosc.org.p1/21-postulatow (data dostępu: 20.02.2016).

${ }^{25}$ T. Kozłowski, Geneza statutu NSZZ Solidarność, „Wolność i Solidarność: Studia dziejów opozycji wobec komunizmu i dyktatury" 2013, nr 6, s. 19-30.

${ }^{26}$ J. Skorzyński, Siła bezsilnych. Historia Komitetu Obrony Robotników, Świat Książki, Warszawa 2012, s. 447-449.

${ }^{27}$ Program NSZZ „,Solidarność” uchwalony przez Krajowy Zjazd Delegatów, s. 87-88.
} 
Delegaci na I Krajowy Zjazd NSZZ Solidarność wzywaja członków zwiąku $i$ wszystkich pracowników do obrony samorzadu pracowniczego. Władze, przerażone perspektywa rozwoju i utrwalania się samorzadu, próbuja zdusić go w zarodku, pozbawiajac prawa zarządzania przedsiębiorstwami, a szczególnie prawa powoływania i odwotywania dyrektorów. (...) Podjęta ostatnio obrona tzw. nomenklatury jest próba utrzymania tego samego systemu doboru kadr, w którym mianowani wedlug kryteriów politycznych kierownicy gospodarki doprowadzili ja do obecnej katastrofy. Oficjalna propaganda utrzymuje, że projekt rzadowy jest ze zrozumieniem przyjmowany przez większość społeczeństwa. W tej sytuacji zjazd, działając zgodnie z pkt 1 art. 8 Konstytucji PRL, która stwierdza: „Prawa Polskiej Rzeczypospolitej Ludowej sq wyrazem interesów i woli ludu pracujacego", zwraca się do Sejmu PRL o podjęcie decyzji o jak najszybszym przeprowadzeniu ogólnonarodowego referendum $w$ sprawie kompetencji samorzadów. Referendum powinno być przeprowadzone przed uchwaleniem ustaw o przedsiębiorstwie i samorzadzie przez Sejm PRL. W ustaleniu pytań i przeprowadzaniu referendum musza brać udziat związi zawodowe. Zjazd postanawia równocześnie, że w przypadku odmowy przeprowadzenia referendum przez organa państwowe, zwiazek przeprowadzi referendum wśród załóg własnymi siłami. Delegaci na I Zjazd oświadczaja, że zwiazek nie zaprzestanie walki o autentyczny samorząd, jak również bezwzględnie bronić będzie swoich członków przed poniesieniem kosztów wynikajacych z reformy niezaakceptowanej przez społeczeństwo. Walkę te prowadzić będziemy przy pomocy wszelkich dostępnych środków. Z catym naciskiem podkreślamy, że w przypadku uchwalenia ustawy o samorzadzie $w$ ksztatcie istotnie odbiegajacym od woli załóg, zwiazek zmuszony będzie podjać bojkot ustawy oraz dziatania zapewniające nieskrępowane funkcjonowanie autentycznym samorzadom ${ }^{28}$.

Władze PRL starały się przeciwstawić postulatom „S”. Na plenum Komitetu Centralnego PZPR we wrześniu 1981 roku zgodzono się wprawdzie z koncepcją rozwoju samorządu pracowniczego, ale jednocześnie przeciwstawiono się ,,anarchizacji” życia gospodarczego. W trakcie negocjacji z „Solidarnością” osiągnięto kompromis, na mocy którego w przypadku przedsiębiorstw strategicznych kadrę kierowniczą miało wybierać państwo, natomiast w pozostałych przypadkach wpływ na obsadę kierownictwa zyskiwała załoga ${ }^{29}$.

Te daleko idące koncepcje nie zostały jednak szerzej wprowadzone w życie, gdyż w grudniu 1981 roku został wprowadzony na terenie PRL stan wojenny, „Solidarność" zdelegalizowano i tym samym zakończono dialog w zakresie utworzenia samorządów robotniczych. W celu pozyskania sympatii robotników rząd utworzył Ogólnopolskie Porozumienie Związków Zawodowych (OPZZ), na czele którego stanął działacz PZPR, Alfred Miodowicz. Kwestia reprezentacji pracowników została podniesiona w trakcie obrad „okrągłego stołu” (luty-kwiecień 1989) pomiędzy władzami PRL a opozycją, jednak wszelkie zmiany były wprowadzane już w III RP, kiedy przestał obowiązywać ustrój socjalistyczny.

\footnotetext{
${ }^{28}$ Zjazd Solidarności - fakty i konteksty [w:] I Krajowy Zjazd Delegatów NSZZ ,, Solidarnośc’. Stenogramy, t. 1 (I tura), oprac. i red. G. Majchrzak, J.M. Owsiński, Warszawa 2011, s. 11-56.

${ }^{29}$ Ibidem, s. 29-35.
} 


\section{Samorząd pracowniczy na Węgrzech w okresie gospodarki centralnie sterowanej}

Niezwykle ciekawym aspektem jest dyskusyjna kwestia istnienia samorządu pracowniczego na Węgrzech. Tak, jak w pozostałych przypadkach, znaczy wpływ na jego kształtowanie się miały uwarunkowania historyczne.

W 1956 roku doszło do wydarzeń, które przeszły do historii jako powstanie węgierskie. Buntownicy domagali się wolności słowa, wprowadzenia demokracji, a także reform gospodarczych. Jednym z postulatów rewolucjonistów było tworzenie rad robotniczych, które spontanicznie zaczęły powstawać w zakładach produkcyjnych. Istniały one jedynie przez krótki okres (kilka dni lub tygodni), wobec czego nie można powiedzieć wiele o ich funkcjonowaniu ${ }^{30}$. Powstanie zostało krwawo stłumione przy wsparciu wojsk ZSRR, a jego uczestnicy poddani represjom. Zapanował terror, a wszystkie obszary życia społecznego i gospodarczego były ściśle kontrolowane przez władze. Uniemożliwiło to działanie samorządów w jakiejkolwiek formie, także samorządów pracowniczych.

Monopol na władzę reżim socjalistyczny utrzymał aż do 1989 roku, jednak stopniowo zezwalano na zmiany w obszarze gospodarki. W 1966 roku został wprowadzony program reform, znany jako Nowy Mechanizm Ekonomiczny. Zakładał on kontynuację systemu centralnego kierowania, przy jednoczesnym zezwoleniu na prowadzenie indywidualnej działalności gospodarczej, np. tworzenie spółdzielni i kooperatyw. Podmioty te mogły samodzielnie ustalać zarówno profil swojej działalności, jak i poziom zatrudnienia ${ }^{31}$. Jednocześnie zwiększono autonomię dyrektorów przedsiębiorstw, którzy sami mogli dysponować nadwyżkami kapitału. Kierowanie sektorem produkcji zostało w znacznym stopniu zdecentralizowane. Ponadto usprawniono także proces podejmowania decyzji o inwestycjach ${ }^{32}$.

Jak pisze Marek Dąbrowski, w przypadku Węgier nie istniał samodzielny samorząd pracowniczy w dosłownym rozumieniu tego terminu. Jednak na podstawie Ustawy o przedsiębiorstwach państwowych załogi uzyskały znaczne uprawnienia w ramach tzw. „demokracji zakładowej”. Kierownictwo przedsiębiorstw było zobowiązane przedstawiać im do akceptacji plany i inne najważniejsze dokumenty ${ }^{33}$. Podobnie rzecz miała się ze wspomnianymi spółdzielniami i kooperatywami. Kierownictwa spółdzielni były wybierane przez jej członków, a więc można mówić tutaj o działaniu w pewnym stopniu podobnym do samorządu pracowniczego.

Na tle zarysowanego powyżej kontekstu historycznego i wskazania pewnych elementów porządku prawnego, w przypadku Węgier należy mówić o samorządzie pracowniczym raczej jako o instytucji nieformalnej, wpasowującej się w ogólną

\footnotetext{
${ }^{30}$ United Nations Report of the Special Committee on the problem of Hungary, Nowy York 1957, s. 17-22.

${ }^{31}$ B. Balassa, The Economic Reform in Hungary, „Economica” 1970, vol. 37, nr 145, s. 4-7.

32 Ibidem, s. 8-9.

${ }^{33}$ M. Dąbrowski, Doświadczenia reform gospodarczych w Jugosławii i na Wegrzech, Instytut Organizacji Zarządzania i Doskonalenia Kadr, Warszawa 1982, s. 7-8.
} 
charakterystykę węgierskich reform, efektem których było powstanie swoistej hybrydy socjalistycznego systemu nakazowo-rozdzielczego $\mathrm{z}$ elementami rynkowymi.

\section{Podsumowanie}

Dla badaczy funkcjonujących w wolnorynkowej i demokratycznej rzeczywistości XXI wieku badania nad procesami gospodarczymi i społecznymi mającymi miejsce w krajach socjalistycznych są zadaniem trudnym. Specyfika ustroju opartego na ideologii marksistowskiej, stanowiącej podporę autorytarnych czy wręcz totalitarnych reżimów uniemożliwia stosowanie bezpośrednich odniesień do czasów nam współczesnych. Problem ten jest widoczny również przy analizach dotyczących samorządu pracowniczego.

Na podstawie przedstawionych rozważań należy stwierdzić, że instytucja samorządu robotniczego w krajach realnego socjalizmu często ulegała deformacji i była wykorzystywana w charakterze narzędzia kontrolowania pracowników, a nie ich partycypacji w zarządzaniu przedsiębiorstwem. Przede wszystkim jednak samorząd robotniczy traktowano jako potencjalną konkurencję dla monopolu władzy partii reżimowych, które rzekome reprezentowanie klasy robotniczej uznawały za dostateczną legitymizację swojej władzy. Jako potwierdzenie tej tezy należy uznać fakt, iż wszelkie próby tworzenia niezależnych organizacji mających reprezentować pracowników spotykały się z bardziej zdecydowaną, a nawet brutalną reakcją władzy, niż np. formowanie opozycyjnych środowisk intelektualistów.

Szczególnie dobrze problem ten da się zaobserwować w Polsce. Zarówno w roku 1956, jak i 1980, protestujący obywatele domagali się umożliwienia wprowadzenia samorządu robotniczego. W obu przypadkach reżim początkowo zezwolił na rozwój tej instytucji, aby potem stłumić ją jako zagrożenie dla monopolu na sprawowanie władzy. Jednocześnie starano się odgórnie rozwijać podporządkowane PZPR związki zawodowe. Podobnie rzecz miała się na Węgrzech, gdzie powstające spontanicznie w 1956 roku rady robotnicze zostały rozpędzone po upadku powstania.

Na tym tle jako wyjątkowy jawi się przypadek Jugosławii. W wyniku konfliktu wewnątrz obozu socjalistycznego zdecydowała się ona na rozwój samorządów robotniczych. Miały one umacniać potencjał gospodarczy państwa i władzę reżimu Tito, a nie ją osłabiać, dlatego nie zostały uznane za zagrożenie. Efektem tego było zbudowanie oryginalnego ustroju gospodarczego opartego na samorządności.

\section{Bibliografia}

Balassa B., The Economic Reform in Hungary, „Economica” 1970, vol. 37, nr 145.

Dąbrowski M., Doświadczenia reform gospodarczych w Jugosławii i na Węgrzech, Instytut Organizacji Zarządzania i Doskonalenia Kadr, Warszawa 1982. 
Dekret z dnia 16 stycznia 1947 r. o zmianie dekretu z dnia 6 lutego 1945 r. o utworzeniu Rad Zakładowych.

Dekret z dnia 6 lutego 1945 r. o utworzeniu Rad Zakładowych.

Fornalczyk A., Jugosłowiański system gospodarczy 1950-1976, Wydawnictwo Łódzkie, Łódź 1979.

Heilbroner R., Wielcy ekonomiści. Czasy, życie, idee, PWE, Warszawa 1993.

Heller M., A. Niekricz, Utopia u władzy. Historia ZSRR od 1917 do dziś, Wydawnictwo CDN, Warszawa 1986.

Konstytucja Polskiej Rzeczpospolitej Ludowej 1976 r.

Kozłowski T., Geneza statutu NSZZ Solidarność, „Wolność i Solidarność: Studia Dziejów Opozycji Wobec Komunizmu i Dyktatury” 2013, nr 6, s. 19-30.

Krajewski S., System zarządzania w przemyśle jugostowiańskim, Książka i Wiedza, Warszawa 1975.

Program NSZZ „Solidarność” uchwalony przez Krajowy Zjazd Delegatów.

Roszkowski W., Historia Polski, 1914-1990, Wydawnictwo Naukowe PWN, Warszawa 1991.

Skodlarski J., Historia gospodarcza, Wydawnictwo Naukowego PWN, Warszawa 2012.

Skorzyński J., Siła bezsilnych. Historia Komitetu Obrony Robotników, Świat Książki, Warszawa 2012.

Statut Polskiej Zjednoczonej Partii Robotniczej uchwalony przez III Zjazd PZPR,1963.

United Nations Report of the Special Committee on the problem of Hungary, UN, Nowy York 1957.

Ustawa z dnia 1 lipca 1949 r. o związkach zawodowych.

Ustawa z dnia 19 listopada 1956 r. o radach robotniczych.

Ustawa z dnia 20 grudnia 1958 r. o samorządzie robotniczym

Zjazd Solidarności -fakty i konteksty [w:] I Krajowy Zjazd Delegatów NSZZ ,, Solidarność”. Stenogramy, t. 1 (I tura), oprac. i red. G. Majchrzak, J.M. Owsiński, Warszawa 2011, s. 11-56.

http://www.solidarnosc.org.pl/21-postulatow. 